\title{
Self-Medication Practices among Medical and Non-Medical Students
}

\author{
Isha Anwar¹, Krishna Minimol², Manjunath Narasimhaiah³
}

${ }^{1}$ Sri Siddhartha Medical College, Tumkur, Karnataka, India. ${ }^{2}$ Sri Siddhartha Medical College, Tumkur, Karnataka, India. ${ }^{3}$ Department of Pharmacology, Sri Siddhartha Medical College, Tumkur, Karnataka, India.

\section{ABSTRACT}

\section{BACKGROUND}

Self-medication practice involves consumption of medicines by one's own initiative or on the consultation of others without the guidance of a doctor. Self-medication and use of over-the-counter drugs, are worldwide health concerns. This study evaluated the prevalence, behavioural patterns, knowledge of self-medication, and the attitudes toward this practice among medical and nonmedical university students.

\section{METHODS}

This is a cross-sectional descriptive study conducted among students with medical and non-medical backgrounds. A semi-structured questionnaire was constructed after reviewing literature to capture data regarding socio-demographic background, practice and knowledge of self-medication.

\section{RESULTS}

Out of a total of 98 students, $79.6 \%$ of students practiced self-medication (medical $77.5 \%$ and non-medical - $85.2 \%$ ). The main reason for self-medication was convenience $(50.8 \%)$ and the choice of self-medication was based on their own experience (30.4\%) and previous doctors' prescription (20.2\%). Community pharmacies $(64.0 \%)$ were the most common source of acquiring the drugs in both groups. It was observed that $53.1 \%$ students think self-medication is an acceptable practice. $28.6 \%$ were confident of treating infectious diseases through selfmedication.

\section{CONCLUSIONS}

The present study shows a higher prevalence of self-medication among students. It also indicates a critical need for the implementation of quality education programs in order to prevent the self-medication among students.

\section{KEY WORDS}

Self-Medication, Medical, Non-Medical
Corresponding Author: Dr. Manjunath GN.

Professor and Head, Department of Pharmacology, Sri Siddhartha Medical College, Tumkur, Karnataka, India E-mail:

manjunathpharmacology@gmail.com

DOI: $10.14260 / j e m d s / 2020 / 652$

How to Cite This Article: Anwar I, Minimol K, Narasimhaiah M. Selfmedication practices among medical and non-medical students. J Evolution Med Dent Sci 2020;9(40):2976-2980, DOI: $10.14260 / \mathrm{jemds} / 2020 / 652$

Submission 29-06-2020,

Peer Review 26-08-2020,

Acceptance 31-08-2020,

Published 05-10-2020.

Copyright (C) 2020 Isha Anwar. This is an open access article distributed under Creative Commons Attribution License [Attribution 4.0 International (CC BY 4.0)] 


\section{BACKGROUND}

Self-medication is a global form of self-care and can be defined as "the taking of drugs, herbs or home remedies on one's own initiative, or on the advice of another person, without consulting a doctor". Prevalence of such practices among doctors and medicos were reported to be $50 \%$ to 76 $\% .{ }^{1}$ Responsible self-medication involves the use of nonprescription, safe, quality medicinal products for conditions that are easily self-diagnosed or for recurrent conditions that have been previously diagnosed by a physician. ${ }^{1}$

According to the World Self-Medication Industry, one of the reasons for self-medication is price and/or time effective. And in most of the low- and middle-income countries, patient care is quite expensive and, in some cases, poorly available and thus making self-medication an obvious choice. ${ }^{3}$ In chronic patients it provides psychological help, by reducing anxiety of shortage of medicines and help to sustain themselves in relieving their symptoms. From a social perspective, selfmedication makes the patients more independent in making decisions in managing minor health conditions, and also saves scarce medical resources. ${ }^{1}$

Over the counter medicines typically include the common medications like pain killers, cough and cold remedies, critically treating cardiovascular disease, vitamins and other essential supplements. ${ }^{2}$ The outcome of this practice can lead to antibiotic resistance, and other serious consequences which can lead to inappropriate dosing, drug duplication, drug interaction, treatment failure, masking of health problems and symptoms, and delay in prescribing the appropriate treatment. ${ }^{3}$ Insomnia, depression, kidney failure, liver cirrhosis and ultimately death are also some of the outcomes of self-medication. ${ }^{4}$

The WHO emphasizes that self-medication must be appropriately communicated and controlled. Although the practice of self-medication is challenging to eliminate, interventions can be made to discourage the indiscreet practice. $^{5}$

Students of both medical and nonmedical background have different levels of education especially related to health sector. This study was done to evaluate the frequency and patterns of self-medication and the behaviour towards this practice among medical and nonmedical students.

\section{METHODS}

This is a cross-sectional study conducted among students with medical and non-medical backgrounds after taking approval from the ethics committee and a valid informed consent. Medical Students from 2nd year and Non-medical students of $3^{\text {rd }}$ year BBA were enrolled into this study. The method adopted was convenient sampling. A structured questionnaire published 6 by Alshogran et al was modified for convenience to capture data regarding socio-demographic background, practice and knowledge of self-medication. The purpose of the study was explained clearly to all the respondents.

The questionnaire was in three sections: section A contained the socio-demographic characteristics of respondents; section B contained questions on self-medication and general awareness; section C - knowledge on antibiotics.

\section{Statistical Analysis}

Data were analysed and presented in frequencies, percentages, means, median and standard deviation. Bivariate analysis was done using chi-square test.

\section{RESULTS}

\section{Demographics Characteristics of Study Participants}

This study was conducted by sending the questionnaire to 220 students (120-medical and 100- non-medical). Out of them only 98 students, responded (71- medical and 27 Nonmedical) with a response rate of 59 and $27 \%$ respectively. The female respondents were slightly more than half (59.2\%), and the mean age was $20.33 \pm 0.85$ years for all participants. (Table-1)

\begin{tabular}{|cccc|}
\hline Characteristics & Medical(N=71) & $\begin{array}{c}\text { Non- } \\
\text { Medical(N=27) }\end{array}$ & Total \\
Male & $24(33.8 \%)$ & $16(59.3 \%)$ & $40(40.8 \%)$ \\
Female & $47(66.2 \%)$ & $11(40.7 \%)$ & $58(59.2 \%)$ \\
Mean Age \pm SD & $20.17 \pm 0.76$ & $20.74 \pm 0.94$ & $20.33 \pm 0.85$ \\
\hline \multicolumn{4}{|c|}{ Table 1. Demographic Characteristics of the Study Participants } \\
\hline
\end{tabular}

\begin{tabular}{|c|c|c|c|c|c|}
\hline 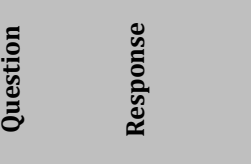 & 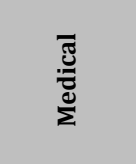 & 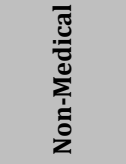 & 퓸 & 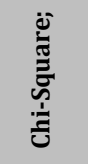 & ڤ్ \\
\hline \multicolumn{6}{|c|}{ 18. Do you know what antibiotics are? } \\
\hline Yes & $68(95.8 \%)$ & $25(92.6 \%)$ & $93(94.9 \%)$ & \multirow{2}{*}{0.381} & \multirow{2}{*}{0.537} \\
\hline No & $3(4.2 \%)$ & $2(7.4 \%)$ & $5(5.1 \%)$ & & \\
\hline \multicolumn{6}{|c|}{ 19. What are antibiotics used for? } \\
\hline Virus infection & $6(8.0 \%)$ & $12(35.3 \%)$ & $18(16.5 \%)$ & 16.902 & $<0.001$ \\
\hline Bacterial infection & $68(90.7 \%)$ & $19(55.9 \%)$ & $87(79.8 \%)$ & 12.669 & $<0.001$ \\
\hline Other & $1(1.3 \%)$ & $3(8.8 \%)$ & $4(3.7 \%)$ & 4.704 & 0.030 \\
\hline \multicolumn{6}{|c|}{ 20. Which of the following statement(s) about antibiotics is (are) correct? 9} \\
\hline $\begin{array}{l}\text { Broad-spectrum } \\
\text { antibiotics are better } \\
\text { than narrow- } \\
\text { spectrum ones }\end{array}$ & $43(50.6 \%)$ & $8(25.0 \%)$ & $51(43.6 \%)$ & 7.500 & 0.006 \\
\hline $\begin{array}{l}\text { Higher doses result in } \\
\text { faster recovery }\end{array}$ & $8(9.4 \%)$ & $7(21.9 \%)$ & $15(12.8 \%)$ & 3.242 & 0.072 \\
\hline $\begin{array}{l}\text { Lower doses result in } \\
\text { less adverse reactions }\end{array}$ & $22(25.9 \%)$ & $7(21.9 \%)$ & $29(24.8 \%)$ & 0.240 & 0.624 \\
\hline $\begin{array}{l}\text { Switching antibiotics } \\
\text { enhances drug effects }\end{array}$ & $6(7.1 \%)$ & $8(25.0 \%)$ & $14(12.0 \%)$ & 7.166 & 0.007 \\
\hline $\begin{array}{l}\text { Switching antibiotics } \\
\text { reduces adverse } \\
\text { reactions }\end{array}$ & $6(7.1 \%)$ & $2(6.3 \%)$ & $8(6.8 \%)$ & 0.028 & 0.866 \\
\hline \multicolumn{6}{|c|}{ Table 2. Level of Knowledge about Antibiotics } \\
\hline \multicolumn{6}{|c|}{ Multiple response variable, statistically significant if $\mathrm{p}<0.05$} \\
\hline
\end{tabular}

\section{Self-Medication Behaviour}

Out of a total of 98 students $79.6 \%$ of students practiced selfmedication (medical- $77.5 \%$ and non-medical- $85.2 \%$ ). The main reason for self-medication was convenience (50.8\%) and the choice of self-medication was based on their own experience (30.4\%) and previous doctors' prescription $(20.2$ $\%)$. Community pharmacies (64.0\%) were the most common source of acquiring the drugs in both groups. (Table-3).

Majority of the participants (49.0\%) always checked the instructions that came with the package for self-treatment $(\mathrm{p}$ $=0.324$ ) only $40.8 \%$ were able to understand $(p=0.005)$. The knowledge about the dosage was known to them by almost all the sources available with least through the media. The dosage was deliberately changed by $57.1 \%$ always or sometimes during treatment $(\mathrm{p}<0.001)$. 


\begin{tabular}{|c|c|c|c|c|c|c|}
\hline Question & Response & Medical & $\begin{array}{c}\text { Non- } \\
\text { Medical }\end{array}$ & Total & $\begin{array}{c}\text { Chi- } \\
\text { Square }\end{array}$ & $\begin{array}{c}P \\
\text { Value }\end{array}$ \\
\hline 1. Have you ever treated yourself (self-medicated)? & Yes & $55(77.5 \%)$ & $23(85.2 \%)$ & $78(79.6 \%)$ & 0.758 & 0.684 \\
\hline 2. Number of times treated yourself in the past 1 year* & - & $2(1-4)$ & $2(1-3)$ & $2(1-4)$ & 897.00 & 0.619 \\
\hline \multirow{4}{*}{ 3. What was (were) your reason(s) of self-medications? I } & Convenience & $47(51.6 \%)$ & $19(48.7 \%)$ & $66(50.8 \%)$ & 0.155 & 0.694 \\
\hline & Others & $34(37.4 \%)$ & $4(10.3 \%)$ & $38(29.2 \%)$ & 9.013 & 0.003 \\
\hline & Cost saving & $7(7.7 \%)$ & $14(35.9 \%)$ & $21(16.2 \%)$ & 20.487 & $<0.001$ \\
\hline & Lack of trust in doctor & $3(3.3 \%)$ & $2(5.1 \%)$ & $5(3.8 \%)$ & 0.409 & 0.522 \\
\hline \multirow[t]{6}{*}{ 4. Your selection of drug was based on recommendations by, } & Own experience & $41(34.5 \%)$ & $10(20.4 \%)$ & $51(30.4 \%)$ & 3.361 & 0.067 \\
\hline & Family members & $21(17.6 \%)$ & $15(30.6 \%)$ & $36(21.4 \%)$ & 5.690 & 0.017 \\
\hline & Previous doctor's prescription & $27(22.7 \%)$ & $7(14.3 \%)$ & $34(20.2 \%)$ & 1.265 & 0.261 \\
\hline & Friends & $16(13.4 \%)$ & $8(16.3 \%)$ & $24(14.3 \%)$ & 0.532 & 0.466 \\
\hline & Pharmacists & $12(10.1 \%)$ & $7(14.3 \%)$ & $19(11.3 \%)$ & 1.019 & 0.313 \\
\hline & Net citizens & $2(1.7 \%)$ & $2(4.1 \%)$ & $4(2.4 \%)$ & 1.053 & 0.305 \\
\hline \multirow[t]{4}{*}{ 5. Where did you usually obtain a drug from for self-medication? } & Community pharmacies & $54(68.4 \%)$ & $19(54.3 \%)$ & $73(64.0 \%)$ & 0.333 & 0.564 \\
\hline & Leftover prescription drugs & $16(20.3 \%)$ & $7(20.0 \%)$ & $23(20.2 \%)$ & 0.125 & 0.723 \\
\hline & Others & $8(10.1 \%)$ & $3(8.6 \%)$ & $11(9.6 \%)$ & 0.0 & 0.983 \\
\hline & Online shopping / E-pharmacies & $1(1.3 \%)$ & $6(17.1 \%)$ & $7(6.1 \%)$ & 12.776 & $<0.001$ \\
\hline \multirow[t]{3}{*}{$\begin{array}{l}\text { 6. Did you ever check the instructions that come with the package for self- } \\
\text { treatment? }\end{array}$} & Yes, always & $32(45.1 \%)$ & $16(59.3 \%)$ & $48(49.0 \%)$ & \multirow{3}{*}{2.253} & \multirow{3}{*}{0.324} \\
\hline & Yes, sometimes & $30(42.3 \%)$ & $7(25.9 \%)$ & $37(37.8 \%)$ & & \\
\hline & Never & $9(12.7 \%)$ & $4(14.8 \%)$ & $13(13.3 \%)$ & & \\
\hline \multirow[t]{3}{*}{ 7. How much did you understand the instructions? } & Fully understood & $32(45.1 \%)$ & $8(29.6 \%)$ & $40(40.8 \%)$ & \multirow{3}{*}{10.506} & \multirow{3}{*}{0.005} \\
\hline & Partially understood & $38(53.5 \%)$ & $14(51.9 \%)$ & $52(53.1 \%)$ & & \\
\hline & Did not understand at all & $1(1.4 \%)$ & $5(18.5 \%)$ & $6(6.1 \%)$ & & \\
\hline \multirow[t]{8}{*}{ 8. How did you know the dosage? 9} & By checking the package insert & $14(11.4 \%)$ & $10(15.6 \%)$ & $24(12.8 \%)$ & 3.173 & 0.075 \\
\hline & By consulting a doctor & $29(23.6 \%)$ & $6(9.4 \%)$ & $35(18.7 \%)$ & 2.955 & 0.086 \\
\hline & By consulting a pharmacist & $15(12.2 \%)$ & $16(25.0 \%)$ & $31(16.6 \%)$ & 13.152 & 0.001 \\
\hline & $\begin{array}{l}\text { By consulting family } \\
\text { members/friends }\end{array}$ & $20(16.3 \%)$ & $12(18.8 \%)$ & $32(17.1 \%)$ & 2.356 & 0.125 \\
\hline & $\begin{array}{l}\text { From the newspapers, } \\
\text { magazines, books, or TV } \\
\text { programs }\end{array}$ & $2(1.6 \%)$ & $3(4.7 \%)$ & $5(2.7 \%)$ & 2.779 & 0.095 \\
\hline & From the Internet & $9(7.3 \%)$ & $9(14.1 \%)$ & $18(9.6 \%)$ & 5.567 & 0.018 \\
\hline & From my previous experience & $30(24.4 \%)$ & $5(7.8 \%)$ & $35(18.7 \%)$ & 4.800 & 0.028 \\
\hline & $\begin{array}{l}\text { By guessing the dosage by } \\
\text { myself }\end{array}$ & $4(3.3 \%)$ & $3(4.7 \%)$ & $7(3.7 \%)$ & 0.885 & 0.347 \\
\hline \multirow[t]{3}{*}{$\begin{array}{l}\text { 9. Did you ever change the dosage deliberately during the course of self- } \\
\text { treatment? }\end{array}$} & Yes, always & $2(2.8 \%)$ & $10(37.0 \%)$ & $12(12.2 \%)$ & \multirow{3}{*}{21.339} & \multirow{3}{*}{$<0.001$} \\
\hline & Yes, sometimes & $35(49.3 \%)$ & $9(33.3 \%)$ & $44(44.9 \%)$ & & \\
\hline & Never & $34(47.9 \%)$ & $8(29.6 \%)$ & $42(42.9 \%)$ & & \\
\hline \multirow{5}{*}{ 10. Why did you change the dosage during the course of self-treatment? $\pi$} & Improving conditions & $25(33.3 \%)$ & $13(38.2 \%)$ & $38(34.9 \%)$ & 1.379 & 0.240 \\
\hline & Worsening conditions & $12(16.0 \%)$ & $10(29.4 \%)$ & $22(20.2 \%)$ & 4.556 & 0.033 \\
\hline & To reduce adverse reaction & $14(18.7 \%)$ & $4(11.8 \%)$ & $18(16.5 \%)$ & 0.314 & 0.575 \\
\hline & $\begin{array}{l}\text { Drug insufficient for complete } \\
\text { treatment }\end{array}$ & $7(9.3 \%)$ & $4(11.8 \%)$ & $11(10.1 \%)$ & 0.482 & 0.487 \\
\hline & Others & $17(22.7 \%)$ & $3(8.8 \%)$ & $20(18.3 \%)$ & 1.983 & 0.159 \\
\hline 11. Did you ever switch drugs during the course of self-treatment? & $\begin{array}{l}\text { Yes, always } \\
\text { Yes, sometimes }\end{array}$ & $33(46.5 \%)$ & $8(29.6 \%)$ & $\begin{array}{l}14(14.3 \%) \\
41(41.8 \%)\end{array}$ & 15.775 & $<0.001$ \\
\hline & Never & $34(47.9 \%)$ & $9(33.3 \%)$ & $43(43.9 \%)$ & & \\
\hline 12. Why did you switch during the course of self-treatment? 9 & The former did not work & $31(47.7 \%)$ & $8(32.0 \%)$ & $39(43.3 \%)$ & 1.608 & 0.205 \\
\hline & The former ran out & $8(12.3 \%)$ & $8(32.0 \%)$ & $16(17.8 \%)$ & 4.828 & 0.028 \\
\hline & The latter one was cheaper & $4(6.2 \%)$ & $2(8.0 \%)$ & $6(6.7 \%)$ & 0.107 & 0.744 \\
\hline & To reduce adverse reactions & $5(7.7 \%)$ & $1(4.0 \%)$ & $6(6.7 \%)$ & 0.379 & 0.538 \\
\hline & Others & $17(26.2 \%)$ & $6(24.0 \%)$ & $23(25.6 \%)$ & 0.032 & 0.857 \\
\hline & Yes, very much & $8(11.3 \%)$ & $5(18.5 \%)$ & $13(13.3 \%)$ & & \\
\hline 13. Are you concerned that counterfeit drugs have been consumed? & Yes, somewhat & $23(32.4 \%)$ & $12(44.4 \%)$ & $35(35.7 \%)$ & 2.999 & 0.223 \\
\hline & No & $40(56.3 \%)$ & $10(37.0 \%)$ & $50(51.0 \%)$ & & \\
\hline $\begin{array}{l}\text { 14. Have you ever found out that you had taken the same drug with } \\
\text { different formulations at the same time? }\end{array}$ & Yes & $23(32.4 \%)$ & $14(51.9 \%)$ & $37(37.8 \%)$ & 3.093 & 0.079 \\
\hline & No & $48(67.6 \%)$ & $13(48.1 \%)$ & $61(62.2 \%)$ & & \\
\hline 15. When did you normally stop taking a drug? ๆ & $\begin{array}{l}\text { After a few days regardless of } \\
\text { the outcome }\end{array}$ & $2(2.6 \%)$ & $8(22.9 \%)$ & $10(9.0 \%)$ & 15.348 & $<0.001$ \\
\hline & After symptoms disappeared & $26(34.2 \%)$ & $12(34.3 \%)$ & $38(34.2 \%)$ & 0.504 & 0.478 \\
\hline & A few days after the recovery & $11(14.5 \%)$ & $8(22.9 \%)$ & $19(17.1 \%)$ & 2.501 & 0.114 \\
\hline & After antibiotics ran out & $5(6.6 \%)$ & $1(2.9 \%)$ & $6(5.4 \%)$ & 0.379 & 0.538 \\
\hline & At completion of course & $32(42.1 \%)$ & $5(14.3 \%)$ & $37(33.3 \%)$ & 5.868 & 0.015 \\
\hline & Others & $0(100 \%)$ & $1(2.9 \%)$ & $1(0.9 \%)$ & 2.657 & 0.103 \\
\hline $\begin{array}{l}\text { 16. What do you think about self-medication with drugs for self-health } \\
\text { care? }\end{array}$ & Good practice & $8(11.3 \%)$ & $11(40.7 \%)$ & $19(19.4 \%)$ & & \\
\hline & Acceptable practice & $40(56.3 \%)$ & $12(44.4 \%)$ & $52(53.1 \%)$ & 11.480 & 0.003 \\
\hline & Not acceptable & $23(32.4 \%)$ & $4(14.8 \%)$ & $27(27.6 \%)$ & & \\
\hline $\begin{array}{l}\text { 17. Do you think you can treat common infectious diseases with drugs } \\
\text { successfully by yourself? }\end{array}$ & Yes, I can & $17(23.9 \%)$ & $11(40.7 \%)$ & $28(28.6 \%)$ & & \\
\hline & Not sure & $34(47.9 \%)$ & $12(44.4 \%)$ & $46(46.9 \%)$ & 3.406 & 0.182 \\
\hline & No, I cannot & $20(28.2 \%)$ & $4(14.8 \%)$ & $24(24.5 \%)$ & & \\
\hline
\end{tabular}

The reason for change of dosage during self-treatment among both groups of students mainly being improving conditions (34.9\%). During the course of treatment, they have switched the drug in $56.1 \%(\mathrm{p}<0.001)$ and the reason being the drug did not work (43.3\%). (Table -3). $49 \%$ participants also believe that they have taken counterfeit drugs. Surprisingly $37.8 \%$ of the participants have taken the same drug with different formulations at the same time $(p=0.079)$.
The main reasons for stopping the drug intake were disappearance of symptoms (34.2\%) and completion of course $(33.3 \%)$. Medical students however mainly stopped the drug usage after completion of course $(42.1 \%)$.

It was observed that $53.1 \%$ students think self-medication is an acceptable practice. And $28.6 \%$ were confident of treating infectious disease through self-medication. $(\mathrm{p}=0.003)$. (Table - 3) 
Out of 98 participants, $94.9 \%$ students were aware of antibiotics ( $\mathrm{p}=0.537)$ and $79.8 \%$ knew that it was used for bacterial infection. Surprisingly medical students responded that broad-spectrum antibiotics are better than narrowspectrum ones (50.6\%). (Table-2).

\section{DISCUSSION}

This study conducted among medical and nonmedical student's found self-medication to be a very common practice in both groups. The common symptoms students primarily treat themselves are pain, common cold and fever. The response rates from the students were poor due to the Covid pandemic. The prevalence of self-medication in our study was $79.6 \%$, slightly more in non-medical students. Previous studies conducted elsewhere showed a prevalence of $40.5 \%$, $44.8 \%$ and $62.9 \% .^{7-9}$ the differences in prevalence between students in our study might be due to the variable sample size or the level of knowledge about self-medication between students. The higher level of self-medication in non-medical students indicates that students are becoming more familiar with medicines and their uses and learn about medications from the internet.

The main reasons for self-medication were observed as "convenience (50.8\%)" and "cost saving (15.2\%)" which was similar in both groups. Other reason for the high prevalence of self-medication being "lack of time to seek physician appointment". ${ }^{10}$ In a study conducted in Kerala convenience (41\%) was the reason for antibiotic self-medication. ${ }^{11}$ Whereas in Egypt the frequently reported causes were "no need to visit the doctor for a minor disease" and the least was "unavailability of health service," while "fear of adverse/side effects" was the most frequent cause for not self-medicating. ${ }^{8}$

In fact, nonmedical students were more dependent on family \& friends and their personal experiences as a source of advice of self-medication, compared to medicos which indicate that they are easily influenced by their friends. The "community pharmacies" are the most common sources to obtain drugs in both the groups. In addition "use of leftover drugs" by medical students and "online E-pharmacies" by nonmedical students was other sources. Another study showed that medical students acquired the drugs from pharmacies, doctor's advice and considered self-medication was not very safe practice. On the other hand, students without healthcare background acquired the drugs from healers and friends. ${ }^{12}$

It is also very important to know the dose of drug to be consumed. The students learnt about dosage by the participants through pharmacists $(25.0 \%)$, previous experiences (24.4\%), consulting a doctor (23.6\%) and family members (18.8\%). In a study conducted in Puducherry $(38.1 \%)^{13}$ and Jordan $(20.7 \%)^{14}$ also had pharmacist (38.1\%) as the main source of their drug usage.

The reasonably positive response observed in our study was the drugs were stopped after completion of course (42.1 $\%)$, disappearance of symptoms (34.2\%) and recovery (22.9 $\%)$. Study conducted in Jordan showed that $65.2 \%$ of participants did not complete their prescribed antibiotic treatment course in the past one year. ${ }^{15}$ It was observed in our study that $53.1 \%$ students think self-medication is an acceptable practice ( $\mathrm{p}=0.003)$ as compared to $47.64 \%$ in a study conducted in Nepal. ${ }^{16}$

Knowledge about antibiotics is very essential in the present days because of the risks of development of resistance. This study showed $94.9 \%$ students were aware of what an antibiotic ( $\mathrm{p}=0.537)$ but only $55.95 \%$ of the non-medical students considered to be used in bacterial infection. This is much higher and better than the study conducted elsewhere. ${ }^{17}$ But preferring broad spectrum over narrow spectrum antibiotics by medical students was highly questionable.

Although self-medication practice was high in this study, awareness about the use of medications was reasonably good. More than half of Medical students read medication instructions every time they purchased a drug, Nevertheless, the university students should be appraised regarding the good and bad consequences of self-medication. Awareness programs has to be conducted regularly especially at the institutions without health background.

\section{CONCLUSIONS}

Self-medication is common among both the both medical and nonmedical students. Although the prevalence is similar among both the groups, some differences exist with respect to medical indications and the type of drugs utilized by them. This practice, if it is not curtailed, can contribute to significant health problems. Creating awareness through interventions by health care regulators is necessary. Small sample size was a limitation of this study.

\section{Way Forward}

The first step towards this objective involves the organization of wide-spread educational workshops and forums which impart knowledge to the public about the nuances of medical drug use. In this regard, regulation of pharmacies is also a critical complementary need to bring down the practice of selfmedication. Policy makers and regulatory authorities also have an important role to play in devising ways to streamline the drug regulation process, and updating the list of essential medicines, as well as safety concerns associated with over-thecounter drugs. A re-evaluated national drugs policy with an essential drugs list, segregating prescription and nonprescription drugs, is thus, an absolute need of the hour.

Authors thank Mr. Riaz a Kalaburgi, Biostatistician and the studentparticipants.

Financial or Other Competing Interests: None.

\section{REFERENCES}

[1] Ruiz ME. Risks of self-medication practices. Curr Drug Saf 2010;5(4):315-23.

[2] Adhikary M, Tiwari P, Singh S, et al. Study of selfmedication practices and its determinant among college students of Delhi University North Campus, New Delhi, India. Int J Med Sci Public Health 2014;3(4):406-9. 
[3] Hernandez-Juyol M, Job-Quesada JR. Dentistry and selfmedication: a current challenge. Med Oral 2002;7(5):3447.

[4] Mensah BN, Agyemang IB, Afriyie DK, et al. Selfmedication practice in Akuse, a rural setting in Ghana. Niger Postgrad Med J 2019;26(3):189-94.

[5] Suja VS, Dutta S, Swaroop AM. Knowledge and perceptions of self-medication practices in an urban community. Asian J Pharm Clin Res 2019;12(8):42-5.

[6] Alshogran OY, Alzoubi KH, Khabour OF, et al. Patterns of self-medication among medical and nonmedical University students in Jordan. Risk ManagHealthc Policy 2018;11:169-76.

[7] James H, Handu SS, Al Khaja KA, et al. Evaluation of the knowledge, attitude and practice of self-medication among first-year medical students. Med Princ Pract 2006;15(4):270-5.

[8] Helal RM, Abou-ElWafa HS. Self-Medication in University Students from the City of Mansoura, Egypt. J Environ Public Health 2017;2017:9145193.

[9] Saba HI, S., Jayan M, Hussain C, et al. Prevalence of selfmedication practices and its associated factors in rural Bengaluru, Karnataka, India. International Journal of Community Medicine And Public Health 20173(6):14816.

[10] Alshogran OY, Alzoubi KH, Khabour OF, et al. Patterns of self-medication among medical and nonmedical University students in Jordan. Risk Manag Healthc Policy 2018;11:169-76.
[11] Rajendran A, Kulirankal KG, Rakesh PS, et al. Prevalence and pattern of antibiotic self-medication practice in an urban population of Kerala, India: a cross-sectional study. Indian J Community Med 2019;44(Suppl 1):S42-5.

[12] Klemenc-Ketis Z, Hladnik Z, Kersnik J. Self-medication among healthcare and non-healthcare students at University of Ljubljana, Slovenia. Med Princ Pract 2010;19(5):395-401.

[13] Selvaraj K, Kumar SG, Ramalingam A. Prevalence of selfmedication practices and its associated factors in Urban Puducherry, India. Perspect Clin Res 2014;5(1):32-6.

[14] Alkhatatbeh MJ, Alefan Q, Alqudah MAY. High prevalence of self-medication practices among medical and pharmacy students: a study from Jordan. Int J Clin Pharmacol Ther 2016;54(5):390-8.

[15] Suaifan GARY, Shehadeh M, Darwish DA, et al. A crosssectional study on knowledge, attitude and behavior related to antibiotic use and resistance among medical and non-medical university students in Jordan. Afr J Pharm Pharmacol 2012;6(10):763-70.

[16] Bhattarai N, Basyal D, Bhattarai N. Self medication practice among undergraduate pharmacy students in Kathmandu Valley, Nepal. Int J Pharm Sci Res 2014;5(11):737-46.

[17] Shehadeh M, Suaifan G, Darwish RM, et al. Knowledge, attitudes and behavior regarding antibiotics use and misuse among adults in the community of Jordan. A pilot study. Saudi Pharm J 2012;20(2):125-33. 